\title{
A Curse or a Blessing? Natural Resources in a Multiple Growth Regimes Analysis
}

\author{
Maty KONTE* \\ GREQAM-Aix-Marseille University
}

This Draft: May, 2011

\begin{abstract}
The literature on the impact of an abundance of natural resources on economic performance remains inconclusive. This paper tests the hypothesis that whether natural resources are a curse or a blessing depends on the growth regime to which economy belongs. We follow recent work that has used a mixture of regression method to identify different growth regimes, and find that in one regime resources are a blessing, while in the other they are a curse or at best have no impact. Our analysis of the determinants of whether a country belongs or not to the blessed resources regime indicates that the level of democracy plays an important role while education has no effect.
\end{abstract}

Key words: Natural Resources, Mixture of regression, Multiple equilibria

*maty_konte@yahoo.fr. 


\section{Introduction}

During the last decade the question of the impact of an abundance of natural resources on growth and its transmission channels has received substantial attention. Despite the extensive literature on the topic, no consensus has emerged on whether natural resources are a curse or a blessing. On the one hand, there is evidence of a negative marginal impact of natural resources on economic performance (see Sachs and Warner (1999), Sachs and Warner (2001), Gylfason (2001), Leite and Weidmann (2002) among others). Different channels of transmission have been proposed to explain the curse, starting with the Dutch Disease (Corden (1984)). It has also been suggested that the curse can be due to rent-seeking behavior that increases tariffs and/or corruption, which in turn reduce growth (see Bardhan (1997), Leite and Weidmann (2002)). Finally, some scholars argue that natural resources crowd-out education (Gylfason (2001)) and quality of institutions (Sachs and Warner (1999)). On the other hand, the success of countries such as Botswana, ${ }^{1}$ rich in natural resources and with high growth rates, challenges the notion of curse.

Recent empirical evidence has thus started to take into account coefficient heterogeneity in order to determine whether there are conditions under which the resource curse can be avoided (see Manzano and Rigobon (2007), Bravo-Ortega and De-gregorio (2007), Mehlum et al. (2006), Collier and Hoeffler (2009)). In fact, taking into account heterogeneity may enable possible bias on estimates to be corrected. Manzano and Rigobon (2007) find no evidence of the resource curse when adding country fixed-effects, while BravoOrtega and De-gregorio (2007), Mehlum et al. (2006) and Collier and Hoeffler (2009) examine how natural resources interact with variables such as education and institutions, to determine the conditions under which the resource curse could be avoided. These previous approaches allow for heterogeneity in the impact of some variables, yet they impose, without testing, common coefficients on most of the regressors, implying that the coefficients on our variable of interest, natural resources may be biased. In this paper we apply a more flexible method to examine heterogeneity, similar to those recently used on multiple growth paths in other circumstances, ${ }^{2}$ and we postulate that the question of whether natural resources are a curse or a blessing depends on the growth regime that a given country belongs to.

We suggest that there may be multiple growth regimes such that the marginal impact of explanatory variables on growth differs across regimes, enabling us to test whether an abundance of natural resources has a negative (or at best neutral) impact on growth in some regimes and a positive impact in other regimes. In line with the literature on natural resources and growth, which has emphasized the role of education and institutions in avoiding the curse, ${ }^{3}$ and in particular the literature on multiple growth paths, which has noted that education, institutions and geography are key determinants of which group

\footnotetext{
${ }^{1}$ Also, Norway, Canada and the United States are examples of countries rich in natural resources but do not suffer from the curse of natural resources.

${ }^{2}$ SeeOwen et al. (2009), Bos et al. (2010), Vaio and Enflo (2011), and Flachaire et al. (2011).

${ }^{3}$ See Bravo-Ortega and De-gregorio (2007), Mehlum et al. (2006), and Collier and Hoeffler (2009).
} 
a country belongs to, ${ }^{4}$ we test whether education, or institutions, or geography affects the probability of a given country belonging to the blessed growth regimes. We estimate a finite mixture of regression model, a semi-parametric method for modeling unobserved heterogeneity in the data, in which countries are sorted into regimes depending on the similarity of the conditional distribution of their growth rates. This approach presents two main advantages. First, we relax the hypothesis of a single growth regime and allow the data to detect the optimal number of regimes, which gives more flexibility and a better fit compared to the literature in which one growth regime is imposed. Second, instead of imposing a priori groups of countries (for instance some studies divide samples into high- and low-income countries), we sort countries into blessed and cursed regimes in terms of their estimated posterior probability of being in one or another regime, which we suppose to be a function of education, institutions and geographic features. We will also show how the different natural resources impact the regimes differently. Our data is best generated by a model of two regimes, one in which an abundance of natural resources has a positive impact on growth and one in which it has a neutral or a negative impact depending on the measure of natural resources that we consider, and more democracy increases the probability of a given country belonging to the blessed regime.

Our paper contributes to the empirical literature on the relationship between natural resources and economic performance. In their seminal work Sachs and Warner (1999) and Sachs and Warner (2001) provide evidence of a negative impact of natural resources on growth and find no support for the idea that geographic features or climate explain the resource curse. Further evidence on the resource curse has been provided by Gylfason (2001), Leite and Weidmann (2002), Papyrakis and Gerlagh (2004) and Papyrakis and Gerlagh (2007), who analyze both the direct impact of natural resources on growth rates and the indirect impact one, operating through the effect of resources on physical and human capital investments.

As recent work has done, we focus on the conditions under which a resource curse can be avoid. Mehlum et al. (2006) show how natural resources interact with an index of rule of law and find that the resources curse disappears when the index of rule of law ${ }^{5}$ is at least 0.93. This value decreases to 0.6 when they replace the export of primary goods in total gdp (also known as Sach and Warner measure of natural resources) by the share of mineral production in national income. Bravo-Ortega and De-gregorio (2007) show how natural resources with education and find that a high level of education helps to reduce the resource curse. Collier and Hoeffler (2009) show how natural resources interact with democracy and stress that in developing countries the combination of high resource rents and an open democratic system is bad for growth but that checks and balances offset this negative effect. Andersen

\footnotetext{
${ }^{4}$ See Durlauf and Johnson (1995) for education and Owen et al. (2009), Flachaire et al. (2011) for institutions and geographical features.

${ }^{5}$ This measure is ranked between 0 and 1.
} 
and Aslaksen (2008) examine whether features of constitutions determine how an abundance of natural resources affects economic growth. They find that the curse is present in democratic presidential countries but not in parliamentary democracies, and that being parliamentary or presidential is more important than being a democracy or an autocracy. All of these papers allow for parameter heterogeneity only in some chosen variables. In fact, when we interact the natural resources measure with for instance, education, we neglect the possible heterogeneity that may exist in the others parameters of the model. We propose a more flexible approach that considers parameter heterogeneity for all the variables of the model, so that countries can belong to different growth regimes. We then examine whether the impact of natural resources on growth differs across regimes. Further compare to the previous literature where authors test in a unique growth model if more education or institutions can avoid the curse, we allow more growth regimes and test whether education and institutions help a given country to belong to the blessed regimes.

Our paper is also related to the literature that tests for the existence of multiple growth processes. Starting with the Classification Analysis and Regression Tree proposed by Durlauf and Johnson (1995), the question of multiple growth regimes has been addressed in numerous papers. Recent work has applied the mixture of regression method to address the multiple regimes hypothesis. Owen et al. (2009) apply the mixture of regression method and find that their panel data is generated by two different growth processes. Using the same methodology, Flachaire et al. (2011) examine the direct and indirect roles of economic and political institutions in the process of development, and their results indicate that political institutions are the main determinant of which growth regime a country belongs to, while economic institutions have an direct impact on growth rates within each of the two regimes. Mixture regressions have also been used by Bos et al. (2010) and Vaio and Enflo (2011) to examine respectively, growth in the very long-run (using an historical data) and the possibility of countries switching regimes. Neither of these papers considers the role of natural resources, yet the framework is obviously suited to examine the question.

The paper proceeds as follows. Section 2 presents the econometric methodology. Section 3 describes the data while section 4 presents the main results. The next section checks the robustness of the results, and some concluding comments are provided in section 6 . 


\section{Econometric specifications}

\subsection{Standard specification}

The standard parametric specification mostly used in growth empirics is of the form: ${ }^{6}$

$$
\begin{gathered}
\text { growth }_{\mathrm{i}, \mathrm{t}}=\beta_{0}+\beta_{1} \log \left(\mathrm{gdp}_{0, \mathrm{i}, \mathrm{t}}\right)+\beta_{2} \log \left(\text { pop }_{\mathrm{i}, \mathrm{t}}+0.05\right)+\beta_{3} \log \left(\mathrm{inv}_{\mathrm{i}, \mathrm{t}}\right)+\beta_{4} \log \left(\operatorname{educ}_{0, i, t}\right) \\
+\beta_{5} \mathrm{NR}_{0, \mathrm{i}, \mathrm{t}}+\beta_{6} \text { eco }_{\mathrm{i}, \mathrm{t}}+\beta_{7} \operatorname{dem}_{\mathrm{i}, \mathrm{t}}+\varepsilon_{i, t}
\end{gathered}
$$

The dependent variable is the average annual growth of real gdp per capita $\left(g r o w t h_{i, t}\right)$ while the independent variables are initial gdp per capita $\left(g d p_{0, i, t}\right)$, the population growth rate $\left(p o p_{i, t}\right)$ plus a term 0.05 capturing depreciation and technological change, the average investment rate $\left(\right.$ inv $\left._{i, t}\right)$, the initial level of education $\left(e d u c_{0, i, t}\right)$, the initial endowment in natural resources $\left(N R_{0, i, t}\right)$, the average level of economic institutions $\left(e \mathrm{co}_{i, t}\right)$ and the average level of democracy $\left(\operatorname{dem}_{i, t}\right)$.

We assume that the error terms $\varepsilon_{i t}$ are identically and independently distributed and follow a normal distribution with mean zero and variance $\sigma^{2}$. Our parameter of interest is the coefficient on the natural resources variable $\beta_{5}$. A negative $\beta_{5}$ confirms the resource curse hypothesis while a positive $\beta_{5}$ implies that resources are a blessing. Economic institutions have been found to be a robust determinant of growth rate in many studies ${ }^{7}$ but there is only weak evidence that political institutions (here measured by democracy) are a robust determinant of growth rates. We expect the coefficient $\beta_{6}$ on economic institutions to be positive and significant while we do not expect a particular sign on the coefficient on democracy, $\beta_{7}$. Political institutions (democracy), have been found to have a weak direct impact on growth but a strong indirect impact through the effect that economic institutions and policies have on growth or through their impact on the choice of policies and economic institutions in a country. ${ }^{8}$

The specification in equation 1 assumes that there is a single growth model which explains the process of development for all countries. If the observations of our dataset are not generated by a single growth regime, the estimation of equation 1 will produce biased results. A biased estimate of the coefficient $\beta_{5}$ could thus lead to the wrong conclusion on whether or not there is a resource curse. To overcome this problem we propose to use the mixture-of-regression method.

\subsection{Finite-mixture-of-regression models}

Finite-mixture-of-regression models, also known as Generalized Mixture Regression Models, are semiparametric methods for modeling unobserved heterogeneity of the population in the estimation of a regression model. We relax the hypothesis of one growth regime and assume $K$ different homogeneous growth regimes such that the growth determinants have different marginal impacts across regimes. Thus

\footnotetext{
${ }^{6}$ See Mankiw et al. (1992).

${ }^{7}$ See Glaeser et al. (2004) and Flachaire et al. (2011) among others.

${ }^{8}$ See Acemoglu et al. (2005), Eicher and Leukert (2009) and Flachaire et al. (2011).
} 
we are able to test whether the marginal impact of an abundance of natural resources on growth differs across regimes. ${ }^{9}$

Let us consider $(Y, X)=\left(y_{i}, x_{i}\right)_{i=1}^{n}$ a pair of a random variable $y_{i}$ and a set of explanatory variables $x_{i}$. By definition, the mixture of regression based on the density of $Y$ conditional on $X$ is expressed as follows:

$$
f(y \mid x, \Theta)=\sum_{k=1}^{K} \pi_{k} f_{k}\left(y \mid x ; \beta_{k}, \sigma_{k}\right)
$$

where $K$ is the number of groups or regimes, $\pi_{k}$ is the probability of belonging to group $k$, and $f_{k}\left(y \mid x ; \beta_{k}, \sigma_{k}\right)$ is a conditional probability distribution characterized by a set of parameters $\left(\beta_{k}, \sigma_{k}\right)$ and of covariates $x$. Both $\beta_{k}$ and $\sigma_{k}$ are unknown and hence estimated. We suppose $f_{k}$ is a Gaussian distribution with conditional expectations equal to $E(y \mid x)=x \beta_{k}$.

To illustrate, if $K=1$, then all observations are generated by the same data-generating process given by:

$$
y=x \beta+\varepsilon, \quad \varepsilon \sim N\left(0, \sigma^{2}\right)
$$

In this case the standard specification in equation 1 is sufficient to study the impact of natural resources on the growth rate. If $K=2$ then a mixture of linear regressions assumes that an observation belonging to the first group and one belonging to the second group would not be generated by the same data-generating process. The mixture model with two components reduces to:

$$
\begin{aligned}
& \text { Group 1: } y=x \beta_{1}+\varepsilon_{1}, \quad \varepsilon_{1} \sim N\left(0, \sigma_{1}^{2}\right) \text {, } \\
& \text { Group 2: } y=x \beta_{2}+\varepsilon_{2}, \quad \varepsilon_{2} \sim N\left(0, \sigma_{2}^{2}\right),
\end{aligned}
$$

where $\varepsilon_{1}$ and $\varepsilon_{2}$ are independent and identical normally distributed error terms within each group, with variances of $\sigma_{1}^{2}$ and $\sigma_{2}^{2}$, respectively. In this setting the impact of natural resources on growth could be different in the two regimes because the environment in which growth occurs is different across regimes. Since we are also interested in testing whether institutions and/or education help to classify countries into growth regimes, we extend the model in equation 2 by adding a set of additional variables $\omega$, also known as concomitant variables, that explain group membership. Concomitant variables play the same role as covariates in a multinomial regression model designed to explain group membership. They directly affect the probability for a given country being in one or another growth regime, implying that parameter $\pi_{k}($.$) becomes endogenous. The roles of standard covariates x$ and of concomitant variables $\omega$ are different: standard covariates help to explain variations within groups, whereas concomitant variables explain variations between groups. Equation 2 with concomitant variables becomes:

$$
f(y \mid x, \omega, \Theta)=\sum_{k=1}^{K} \pi_{k}\left(\omega, \alpha_{k}\right) f_{k}\left(y \mid x ; \beta_{k}, \sigma_{k}\right),
$$

\footnotetext{
${ }^{9}$ To avoid repetition we will not give all the steps of the functional form of the mixture of regression methods for panel data. For more details the reader is invited to refer to Owen et al. (2009).
} 
where $\alpha_{k}$ is a vector of parameters on concomitant variables $\omega$ and its sign helps to determine how a variation of $\omega$ impacts the probabilities of countries being in one or another regime.

For a given number of components $K$ we estimate the finite mixture model by maximum likelihood with the EM algorithm of Dempster et al. (1977), which is the most common approach for the maximum likelihood estimation of finite mixture models. To avoid a singularity problem we ensure that the estimated parameter of $\sigma_{k}$ is different from zero. The number of groups $K$ is a priori unknown and the selection of the optimal value is crucial since it gives the true number of growth regimes generated by the data. We choose the optimal value of $K$ by minimizing the Bayesian Information Criterion (BIC) developed by Schwarz (1978), and the Corrected Information Criterion (CAIC, see Sugiura (1978), and Hurvich and Tsai (1989)). Those criteria are defined as follow:

$$
\begin{gathered}
\mathrm{BIC}=-2 \hat{\ell}+(\# \text { param }) \log n \\
\mathrm{CAIC}=-2 \hat{\ell}+\frac{(\# \text { param }) 2 n}{n-(\# \text { param })-1}
\end{gathered}
$$

where $\hat{\ell}$ is the estimated value of the $\log$-likelihood and $n$ is the number of observations. Once parameters are estimated, we can use Bayes rule to compute the probability that a given country is allocated to a given group $k$. The equation is written as follows:

$$
\hat{\pi}_{i k}=\frac{\pi_{k}\left(w_{i}, \hat{\alpha}_{k}\right) f_{k}\left(y_{i} \mid x_{i} ; \hat{\beta}_{k}, \hat{\sigma}_{k}\right)}{\sum_{k=1}^{K} \pi_{k}\left(\omega_{i}, \hat{\alpha}_{k}\right) f_{k}\left(y_{i} \mid x_{i} ; \hat{\beta}_{k}, \hat{\sigma}_{k}\right)}
$$

For classification purposes, a given country $i$ will be allocated in group $k$ rather than group $l$ if and only if $\hat{\pi}_{i k}>\hat{\pi}_{i l}$.

We will apply the mixture of regression method on the standard equation 1 defined in section 2.1, using as concomitant variables average levels of economic institutions $(\overline{e c o})$, democracy $(\overline{d e m})$ and the initial level of education ( $\left.e d u c_{70}\right)$, as well as Latitude (Lat) to the set of concomitant variables.

The use of the mixture of regression models has three advantages. First, it allows to threat endogenously unobserved heterogeneity by considering simultaneously all the covariates and allowing them to have different marginal impacts across regimes. Second, countries are sorted into regimes in terms of probabilities which are a function of concomitant variables, thus we can compare the role of education and institutions in allocating countries into regimes. Finally, the number of homogeneous growth regimes is a priori unknown and are selected optimally with respect to some information criterion. This means that if there are more than two ways in which resources affect growth, we should be able to identify them. It is important to note that our approach does not consider the indirect impact of natural resource through variables such as investment or education, a question that has received substantial attention in the literature (See Gylfason (2001)). In addition our model constrains countries not to be in different 
regimes at different periods since the concomitant variables are constant. ${ }^{10}$

\section{$3 \quad$ Data and descriptive statistics}

We build a 5-year panel of developed and developing countries for the period 1970-2005, which yields 7 periods: 1970-1975, 1975-1980, 1980-1985, 1985-1990, 1990-1995, 1995-2000 and 2000-2005. All the variables used except education, the measures of natural resources and institutions are from the Penn World Tables (version 6.3). Education comes from Barro and Lee (2010) and is measured by the average years of schooling in the population aged over 25. Our main measure of natural resource abundance is the share of exports of primary goods in total GDP $(x g d p)$ which includes fuel and non-fuel goods. This measure, first proposed by Sachs and Warner (1999), has been extensively used in the literature. The data are provided by the World Development Indicators (WDI). Non-fuels goods comprise metals and ores, agricultural raw materials and food. In our analysis we will first use the aggregate measure of natural resources $(x g d p)$. Sachs and Warner (2001) argue that the natural resources effect should be linked to the magnitude of economic rents they generate, hence we will distinguish minerals from agricultural goods since minerals yield in general higher rents. We will also disaggregate $x g d p$ into its three components ${ }^{11}$ : metal and ores (Metal-Ores), agricultural raw materials and food (Agri-food) and fuel (Fuel). Some authors (for instance Gylfason (2001)) define the share of primary exports as natural resources intensity rather than natural resources abundance, ${ }^{12}$ so we will further use the rent per capita, ${ }^{13}$ as a measure for natural resources abundance in the robustness part in section 5 .

Turning to the measures of institutions, we distinguish political institutions from economic institutions. Political institutions refer to how political choices are made while economic institutions refer to the consistency of those choices with voluntary exchange and the protection of property rights. We measure political institutions by the index of democracy from Polity IV, and economic institutions by the index of the Economic Freedom in the world from the Fraser Institute compilation. ${ }^{14}$ The democracy index takes into account the competitiveness of executive recruitment, the openness of executive recruitment,

\footnotetext{
${ }^{10}$ The question of regime migration is a complex one and has been recently addressed by Bos et al. (2010).

${ }^{11}$ As documented in the World Bank data Agricultural raw materials exports correspond to the SITC section 2 excluding divisions 22, 27 (crude fertilizers and minerals excluding coal, petroleum, and precious stones), and 28 (metalliferous ores and scrap); Food exports Food comprises the commodities in SITC sections 0 (food and live animals), 1 (beverages and tobacco), 4 (animal and vegetable oils and fats) and SITC division 22 (oil seeds, oil nuts, and oil kernels); Ores and metals comprise the commodities in SITC sections 27 (crude fertilizer, minerals nes) 28 (metalliferous ores, scrap), and 68 (non-ferrous metals) and Fuel exports comprise SITC section 3 (mineral fuels).

${ }^{12}$ The idea behind is that a country like Norway, has a low share of exports of primary products in total GDP because it has also developed the others sectors of the economy.

${ }^{13}$ Rent is defined as total revenue from natural resources divided by the population. The rent is provided by the WDI and it includes rent from energy, minerals and forest. Energy refers to crude oil, natural gas and coal, and mineral refers to bauxite, copper, iron, lead, nickel, tin, zinc, gold and silver. The rent of a unit of resource is defined as the gap between its world price and its country-specific extraction costs both expressed in US dollars, the obtained measure is then multiplied by the total quantity of resources extracted.

${ }^{14}$ These two measures are used in Flachaire et al. (2011) where authors explain how political and economic institutions enhance differently the economic development of countries
} 
the constraints on the executive, and the competitiveness of political participation. It ranges between 0 and 10, with a value of 0 denoting an autocratic government and a value of 10 full democracy. Economic freedom measures the extent to which property rights are protected and the freedom that individuals have to engage in voluntary transactions. This measure takes into account the respect of personal choices, the voluntary exchanges coordinated by markets, freedom to enter and compete in markets, and protection of persons and their property from aggression by others.

Table 1 shows the descriptive statistics and data sources. Let us note that $\overline{e c o}, \overline{d e m}$ and $e d u c_{1970}$ are concomitant variables where $\overline{e c o}$ and $\overline{d e m}$ are the average value of economic institutions and democracy over the period 1970-2005, and $e d u c_{1970}$ is the level of education in 1970. Table 2 shows the correlation coefficients between variables. The correlation between the growth rate and the aggregate natural resources variable $(x g d p)$ is negative, in line with the resource curse theory. In addition $x g d p$ is negatively correlated with investment in physical and human capital $\left(\log (i n v), \log \left(e d u c_{0}\right)\right)$; the latter variables are in turn positively correlated with the growth rate. This may suggest that there is an indirect negative impact of natural resources on growth through the investments in physical and human capital as already found in the literature (see Gylfason (2001), Atkinson and Hamilton (2003), Papyrakis and Gerlagh (2004)). Turning to the correlations between natural resources and institutions, the natural resource measure $(x g d p)$ is negatively correlated with both measures of institutions but the correlation with democracy is much higher. When we consider the disaggregated measures of natural resources only the measure of fuel (Fuel) is correlated positively with the growth rate, initial gdp per capita and investment in physical capital.

\section{Results and discussion}

\subsection{Standard model results}

We start by reproducing some of the results found in the literature. Table 3 presents OLS estimates as well as fixed and random effect estimations. We use the aggregate measure of natural resources $(x g d p)$. In this and all subsequent tables $N R$ always denotes natural resources, which can be measured in different ways. The first column reports the OLS estimates for the cross-section. The coefficient on natural resources is negative and significant at the conventional level 1\%, suggesting that an abundance of natural resources reduces growth. The coefficient on $N R(-0.044)$ is roughly comparable to that in Sachs and Warner (2001), table 2 columns (2) and (3), where the resource curse hypothesis is analysed for the period 1970-1989. For the panel data we estimate the pooled, random-effects and fixed-effects models with or without instrumenting education and institutions. Results are reported in columns (2)-(6) of table 3 . The coefficient on natural resources is negative in almost all columns but it is never significant. This confirms 
the results in Manzano and Rigobon (2007) who find that the resource curse hypothesis disappears once panel data with fixed-effects are used. Turning now to the other variables in the regression, the negative signs on initial gdp $\log (g d p)$ are consistent with the beta-convergence hypothesis between countries and the coefficients on the economic institutions, eco, have the expected sign and are significant at the $1 \%$ level. Not surprisingly more democracy does not stimulate growth, as already found in previous work. ${ }^{15}$

These results support neither a resource curse nor a resource blessing is supported when using standard models on panel data. One possible cause for the absence of significant coefficients on natural resources is that there exists unobserved heterogeneity in the data. In fact the assumption that all countries follow the same growth regime may be too constraining, raising a doubt on the quality of the estimators. Hence we suppose that our data could be generated by multiple growth regimes that we do not know a priori, and an abundance on natural resources may have different marginal impacts across regimes. Under this assumption we apply the mixture of regression method to take into account heterogeneity. Although the panel fixed-effect takes into account the heterogeneity in the constant, term the mixture of regression method has the advantage of taking into account endogenously the heterogeneity on the explanatory variables by allowing them to have different marginal impacts across growth regimes.

\subsection{Mixture-of-regression results}

We next estimate the mixture model with concomitant variables and allow the number of groups $K$ to vary between 1 and 4, estimating 4 models. We report the values of the BIC and CAIC in table 4 . Both of the information criteria are minimized for $\mathrm{K}=2$, allowing us to select the model with two growth regimes as the model that best fits the data. According to the two test statistics, the two-regime model presents a substantial improvement over estimating a single regime model. Recall that the estimations of the model where $\mathrm{K}=1$ is reported in column (2) of table 3 , where we found no impact of natural resources on growth rate.

Table 5 shows the estimated parameters of the selected mixture model. The coefficients on natural resources support our hypothesis that an abundance of natural resources has different impacts on growth across regimes. While there is a resource blessing in the first regime, an abundance of natural resources is neutral in the second regime. We also test whether the coefficients on $N R$ are statistically different across regimes, reporting the Wald test in column 3. The null hypothesis under which the coefficients on $N R$ are equal across the two growth regimes is statistically rejected by the Wald test at the $5 \%$ level. The coefficients on initial income, on investment in physical and human capital and on institutions are also statistically different across regimes. Investments in physical and human capital have a positive and

\footnotetext{
${ }^{15}$ Barro (1996), Glaeser et al. (2004) and Flachaire et al. (2011) support that the empirical evidence does not establish a direct link between political institutions and economic performance.
} 
significant impact on growth for the first group, but education does not affect growth for the second one. Economic institutions are beneficial for growth in both regimes while political institutions do not matter for the second regime but affect negatively the growth rate in the first group.

We turn now to the coefficients on the concomitant variables. Recall that the concomitant variables play the same role as covariates in the multinomial logit estimations, so that only the signs of the coefficients have an interpretation. Our group of reference here is the first one, the one for which resources have a positive impact on growth. The results show a positive and very significant coefficient on democracy, indicating that an increase of the level of democracy decreases the probability for a given country to be in the second regime rather than in the first regime. also the latitude helps to split countries into regimes. Both economic institutions and education do not affect the regime membership probability.

We find that $35 \%$ of countries are in the first group against $65 \%$ in the second group. Table 6 shows the classification of countries into growth regimes with their respective probability. Some countries from different regions and countries with different levels of development follow the same growth process. For instance Bangladesh, the Republic of Congo and Mali in the same group as most of the Western countries, while Ireland and Portugal are in the same group as most of poor countries.

Table 7 reports the average values of the dependent and independent variables for the two groups with the within group standard deviations in parenthesis. The average growth rate is equal to $2.32 \%$ for the first group against $1.50 \%$ for the second group. The standard deviation is much lower in the first group than in the second group which could be explained by the high diversity of countries in the first group. The average value of exports of primary goods is twice as low in the first group as in the second. Regarding institutions, there is only a small difference on the average values of economic institutions but the level of democracy is much higher in the first group than in the resource blessing group.

\section{Robustness Analysis}

To test the robustness of our results we run a number of further estimations. First, we use different measures for natural resources, the disaggregated components of our main measure $x g d p$ and the rent per capita in logs. Second, we will include an interaction term between natural resources and education. Lastly, we will use alternative measures of political institutions which have been previously found to be important for the classification of countries into growth regimes.

\subsection{Alternative measures for natural resources}

Table 8 shows additional evidence on the existence of two growth regimes when we use alternative measures of natural resources, as the information criterion selection always gives 2 growth regimes. We report the estimations of the $\mathrm{K}=2$ mixture models in table 9 . For Metal - Ores, the results support 
the existence of a resource blessing in the first regime and a resource curse in the second regime. The level of democracy helps split countries into regimes, with more democracy increasing the probability for a given country to be in the resources blessing regime. The Wald test, which is not reported, rejects the hypothesis of the equality of the coefficients on natural resources across regimes. Similarly, when we consider agricultural raw and food (Agri-Food) as the measure of natural resource abundance, we find again a resource blessing in the first regime and resources curse in the second regime. For Fuel we have no effect of natural resources on growth in the second regime and a positive one in the first. In all cases the level of democracy is an important determinant of the probability for countries to be classified into regimes, while education and regional dummies tend to play no role. Only in the case of Fuel the Latin American dummy decreases the probability to be in the resources blessing regime. Note that the magnitude of the coefficient on natural resources in absolute value is higher for Metal - Ores than for Agri-food and Fuel. One possible explanation is that mineral sectors yield in general higher rents than agricultural sectors and fuel sectors (see Sachs and Warner (2001)).

Considering rent per capita as our measure of resources, we find resource blessing in the first group but no impact in the second one. As before, the level of democracy enhances the classification of countries into regimes, while the Sub-Africa dummy is now significant indicating that being a Sub-Africa country reduces the probability to belong to the blessed resource group.

\subsection{Education and natural resources}

Education has been found to be important in the resource curse literature (see Gylfason (2001) and Bravo-Ortega and De-gregorio (2007)) but our previous results do not show that education helps to split countries into blessed and cursed regimes. One possibility is that education has a different role, such as a direct impact on the coefficient on natural resources. Following Bravo-Ortega and De-gregorio (2007) who interact education and natural resources in order to examine whether an increase in the level of education decreases the negative impact of natural resources on growth, we add the term $(\log (e d u c) * N R)$ to the regressors. For ease of computation we also exclude all the concomitant variables that where never significant in the previous estimations. The values of the information criteria are not reported, but the model with two growth regimes is again selected for each of the measures of natural resources we consider. The estimations of the selected models are reported in table 10. Our result that natural resources have a positive impact in one regime but a negative or neutral effect in the other is robust, and democracy still helps to split countries into regimes. When we use the aggregated measure $x g d p$ and the rent per capita Rent as the measures of natural resource the coefficient on the interact term $\left(\log (\text { educ })^{*} \mathrm{NR}\right)$ indicates that more education decreases the marginal effect of natural resource on growth in the blessed regime (or group 2). However, when we replace the measure of natural resource by Ores - Metal results show that 
more education decreases the resource curse. There are no other important changes in the coefficients on the other explanatory variables.

\subsection{Alternative measures for democracy}

Our last specification to check the robustness of our results is to change the measure of democracy that we find important in the classification of countries. We replace the Polity IV measure with data from Golder (2005). These data provide measures for a wide range of institutions including regime type, the electoral system and the assembly size. Data are available for a large number of countries over the 1946-2000. We use demautoc, a dummy which is equal to 1 for democracies and 0 for autocracies. As explanatory variable we take the initial value of demautoc at the beginning of each period and as concomitant variable the value in 1970 . We will also add to the concomitant variables a dummy denoted presdem $m_{70}$ which is equal to 1 for presidential democracies in 1970 and 0 for parliamentary or mixed democracies. ${ }^{16}$ Results are reported in table 11. We find again two growth regimes whereby an abundance of natural resources is beneficial in one regime and negative or neutral in the other. Being a democracy remains a key determinant of the probability of being in the blessed regime but the type of democratic system does not matter for the classification of countries into regimes.

\section{Conclusion}

Future works on the link between natural resources and economic development should consider the indirect mechanism of the curse by modeling a system of simultaneous equations using a mixture of regression approach.

\section{References}

Acemoglu, D., S. Johnson, J. A. Robinson, and P. Yared (2005). From education to democracy? American Economic Review Papers and Proceedings 95, 44-49.

Andersen, J. and S. Aslaksen (2008). Constitutions and the resource curse. Journal of Development Economics 87, 227-246.

Atkinson, G. and K. Hamilton (2003). Savings, growth and the resource curse. World Development 31, $1793-1807$.

Bardhan, P. (1997). Corruption and development: A review of the issues. Journal of Economic Literature 35, 1320-1346.

\footnotetext{
${ }^{16}$ See Persson (2005) for the role of constitutions on economic development and Andersen and Aslaksen (2008) for natural resources and constitutions.
} 
Barro, R. (1996). Democracy and growth. Journal of Economic Growth 1, 1-27.

Barro, R. and J.-W. Lee (2010). A new data set of educational attainment in the world, 1950-2010. NBER Working Paper No. 15902.

Bos, J., C. Economidou, M. Koetter, and J. Kolari (2010). Do all countries growth alike? Journal of Development Economics 91, 113-127.

Bravo-Ortega, C. and J. De-gregorio (2007). The relative richness of the poor? Natural resources, human capital and economic growth. In D. Lederman and W. F. Maloney (Eds.), Natural Resources: Neither curse nor destiny, pp. 71-99.

Collier, P. and A. Hoeffler (2009). Testing the neocon agenda: Democracy in resource-rich societies. European Economic Review 53, 293-308.

Corden, W. M. (1984). Booming sector and Dutch Disease economics: Survey and consolidation. Oxford Economics Papers 36, 359-380.

Dempster, A. P., N. M. Laird, and D. B. Rubin (1977). Maximum likelihood from incomplete data via EM algorithm (with discussion). Journal of the Royal Statistical Society B 39.

Durlauf, S. and P. A. Johnson (1995). Multiple regimes and cross-country behavior. Journal of Applied Econometrics 10, 365-384.

Eicher, T. and A. Leukert (2009). Institutions and economic performance: Endogeneity and parameter heterogeneity. Journal of Money, Credit and Banking 41, 197-219.

Flachaire, E., C. Garcia-Peñalosa, and M. Konte (2011). Political versus economic institutions in the growth process. CESifo working paper No. 3432.

Glaeser, E., R. La Porta, F. Lopez-de-Silanes, and A. Shleifer (2004). Do institutions cause growth? Journal of Economic Growth 9, 271-303.

Golder, M. (2005). Democratic electoral system around the world, 1946-2000. Electoral Studies.

Gylfason, T. (2001). Natural resources, education, and economic development. European Economic Review 45, 847-859.

Hurvich, C. and C. Tsai (1989). Regression and time series model selection in small samples. Biometrika $76(2), 297-307$.

Leite, C. and J. Weidmann (2002). Does Mother Nature Corrupt? Natural Resources, Corruption, and Economic Growth. In G. T. Abed and S. Gupta (Eds.), Governance, Corruption and Economic Performane, pp. 71-99. International Monetary Fund. 
Mankiw, N., D. Romer, and D. Weil (1992). A contribution to the empirics of economic growth. Quarterly Journal of Economics 10\%, 407-437.

Manzano, O. and R. Rigobon (2007). Resource curse or debt overhang? In D. Lederman and W. F. Maloney (Eds.), Natural Resources: Neither curse nor destiny, pp. 41-70.

Mehlum, H., K. Moene, and R. Torvik (2006). Institutions and resource curse. The Economic Journal 116, 1-20.

Owen, A., J. Videras, and L. Davis (2009). Do all countries follow the same growth process? Journal of Economic Growth 14, 265-286.

Papyrakis, E. and R. Gerlagh (2004). The resource curse hypothesis and its transmission channels. Journal of Comparative Economics 32, $181 ? 193$.

Papyrakis, E. and R. Gerlagh (2007). Resource abundance and economic growth in the united states. European Economic Review 51, 1011-1039.

Persson, T. (2005). Forms of Democracy, Policy and Economic Development. NBER Working Paper No. 11171.

Sachs, J. and A. Warner (1999). The big push, natural resource booms and growth. Journal of Development Economics 59, 43-76.

Sachs, J. and A. Warner (2001). Natural resources and economic development the curse of natural resources. European Economic Review 45, 827-838.

Schwarz, G. (1978). Estimating the dimension of a model. Annals of Statistics 6, 461-464.

Sugiura, N. (1978). Further analysis of the data by akaike's information criterion and the finite corrections. Communications in Statistics, Theory and Methods 7, 13-26.

Vaio, G. D. and K. Enflo (2011). Did globalization drive convergence? Identifying cross-country growth regimes in the long-run. European Economic Review, forthcoming. 


\begin{tabular}{|c|c|c|c|c|c|c|c|}
\hline Variable & Obs. & Mean & SD & Min & $\operatorname{Max}$ & Description & Data source \\
\hline growth & 498 & 1.82 & 2.75 & -13.60 & 11.07 & Average annual growth rate & PWT 6.3 \\
\hline $\log (g d p)$ & 498 & 8.77 & 1.01 & 6.43 & 10.64 & Log of initial real GDP per capita & PWT 6.3 \\
\hline $\log (p o p+0.05)$ & 498 & 1.89 & .16 & 1.49 & 2.33 & $\begin{array}{l}\text { Log of population growth }+ \text { technol- } \\
\text { ogy growth }+ \text { depreciation rate }\end{array}$ & PWT 6.3 \\
\hline $\log (i n v)$ & 498 & 3.01 & .50 & 1.25 & 4.05 & Log of investment rate & PWT 6.3 \\
\hline $\log (e d u c)$ & 498 & 1.58 & .68 & -1.64 & 2.57 & $\begin{array}{l}\text { Log of initial average years of educa- } \\
\text { tion of the total population aged over } \\
25\end{array}$ & Barro and Lee 2010 \\
\hline dem & 498 & 5.83 & 3.99 & 0 & 10 & $\begin{array}{l}\text { Political institutions: degree of } \\
\text { democracy (Polity IV) }\end{array}$ & $\begin{array}{l}\text { www.systemicpeace.org, } \\
\text { Polity IV project }\end{array}$ \\
\hline eco & 498 & 6.01 & 0.81 & 2.68 & 8.66 & $\begin{array}{l}\text { Economic institutions: index of Eco- } \\
\text { nomic Freedom of the World }\end{array}$ & $\begin{array}{l}\text { www.freetheworld.com, } \\
\text { version } 2009\end{array}$ \\
\hline $\operatorname{xgdp}$ & 498 & 12.92 & 12.43 & .23 & 76.07 & $\begin{array}{l}\text { Initial level of exports of primary } \\
\text { goods over total gdp }\end{array}$ & $\begin{array}{l}\text { World Development In- } \\
\text { dicators }(2010)\end{array}$ \\
\hline Metal-Ores & 492 & 2.14 & 5.74 & $<0000$ & 55.44 & $\begin{array}{l}\text { Initial level of exports of metal and } \\
\text { ores over total gdp }\end{array}$ & $\begin{array}{l}\text { World Development In- } \\
\text { dicators }(2010)\end{array}$ \\
\hline Agri-food & 498 & 6.92 & 7.25 & .001 & 44.15 & $\begin{array}{l}\text { Initial level of exports of agriculture } \\
\text { and food goods over total gdp }\end{array}$ & $\begin{array}{l}\text { World Development In- } \\
\text { dicators }(2010)\end{array}$ \\
\hline Fuel & 482 & 4.01 & 9.08 & $<0000$ & 63.12 & $\begin{array}{l}\text { Initial level of exports of fuel over to- } \\
\text { tal gdp }\end{array}$ & $\begin{array}{l}\text { World Development In- } \\
\text { dicators }(2010)\end{array}$ \\
\hline $\log \left(e d u c_{1970}\right)$ & 91 & 1.58 & 0.89 & -1.64 & 2.39 & $\begin{array}{l}\text { Log of initial average years of educa- } \\
\text { tion of the total population aged over } \\
25\end{array}$ & Barro and Lee 2010 \\
\hline$\overline{d e m}$ & 91 & 5.19 & 3.54 & 0 & 10 & $\begin{array}{l}\text { Political institutions: degree of } \\
\text { democracy (Polity IV) }\end{array}$ & $\begin{array}{l}\text { www.systemicpeace.org, } \\
\text { Polity IV project }\end{array}$ \\
\hline$\overline{e c o}$ & 91 & 1.01 & 1.07 & 4.31 & 8.14 & $\begin{array}{l}\text { Economic institutions: index of Eco- } \\
\text { nomic Freedom of the World }\end{array}$ & $\begin{array}{l}\text { www.freetheworld.com, } \\
\text { version } 2009\end{array}$ \\
\hline
\end{tabular}

Table 1: Data descriptive and sources

\begin{tabular}{|c|c|c|c|c|c|c|c|c|}
\hline & growth & $\log (g d p)$ & $\log (p o p+0.05)$ & $\log (i n v)$ & $\log (e d u c)$ & dem & eco & xgdp \\
\hline growth & 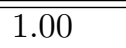 & & & & & & & \\
\hline $\log (g d p)$ & 0.06 & 1.00 & & & & & & \\
\hline $\log (p o p+0.05)$ & -0.21 & -0.66 & 1.00 & & & & & \\
\hline $\log (i n v)$ & 0.24 & 0.58 & -0.43 & 1.00 & & & & \\
\hline $\log (e d u c)$ & 0.11 & 0.77 & -0.59 & 0.45 & 1.00 & & & \\
\hline dem & 0.07 & 0.63 & -0.62 & 0.38 & 0.63 & 1.00 & & \\
\hline eco & 0.26 & 0.58 & -0.41 & 0.33 & 0.51 & 0.46 & 1.00 & \\
\hline xgdp & -0.07 & -0.16 & 0.33 & -0.06 & -0.12 & -0.28 & -0.08 & 1.00 \\
\hline
\end{tabular}

Table 2: Coefficients of correlation 


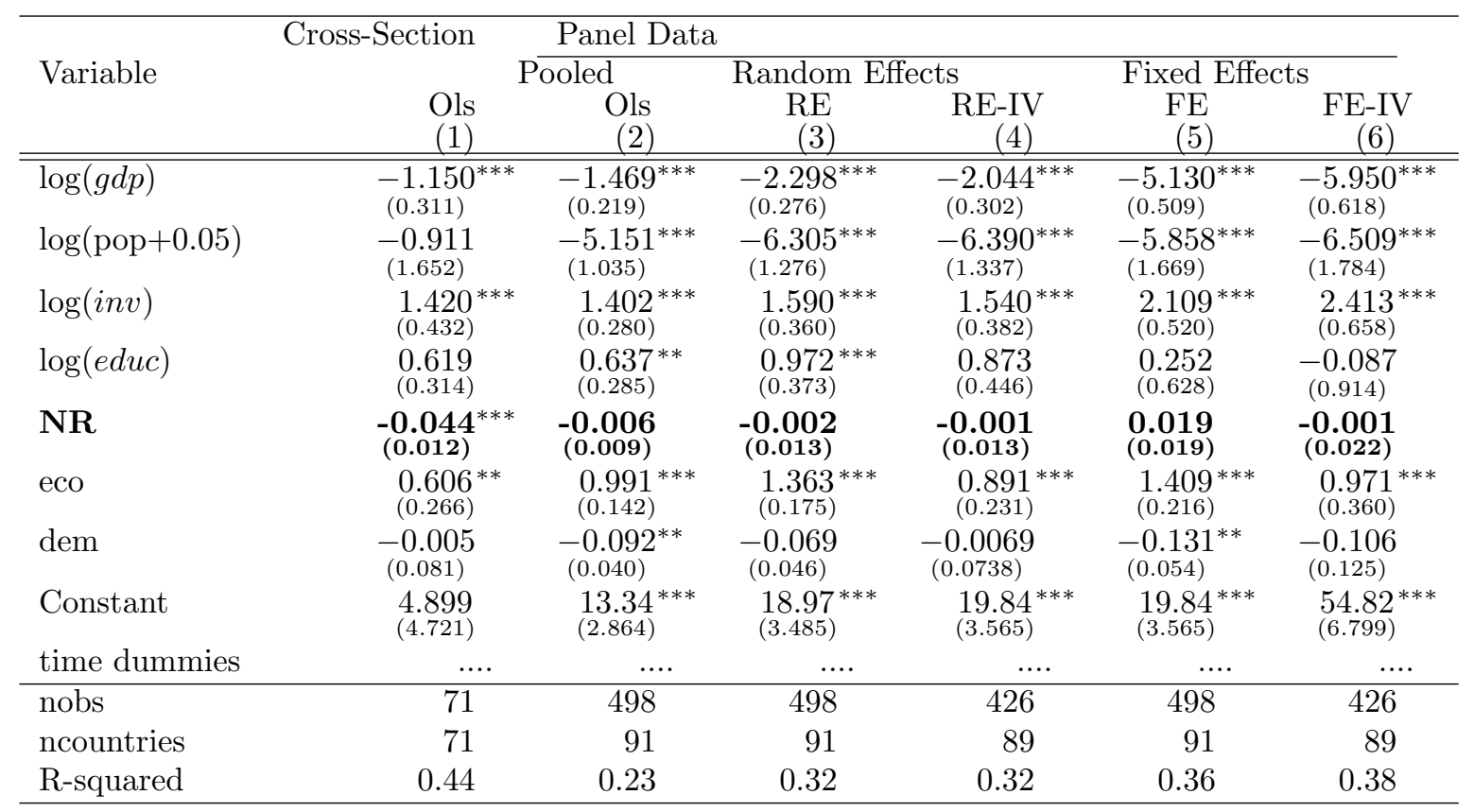

Table 3: Standard estimations. We use the aggregate measure of exports of primary goods $x g d p$ for the natural resources variable. Time dummies are include for panel data estimations. For IV estimation, first lags of $\log \left(\right.$ educ), dem and eco are used as instruments. Standard Errors are in parenthesis, ${ }^{* * *}$ significant at $1 \%, * *$ significant at $5 \%$. 


\begin{tabular}{lcc}
\hline & BIC & CAIC \\
\hline \hline $\mathrm{K}=1$ & 2353.8 & 2368.8 \\
$\mathbf{K}=\mathbf{2}$ & $\mathbf{2 2 8 2 . 6}$ & $\mathbf{2 3 1 7 . 6}$ \\
$\mathrm{K}=3$ & 2293.1 & 2348.1 \\
$\mathrm{~K}=4$ & 2309.8 & 2384.8 \\
\hline
\end{tabular}

Table 4: Selection of the mixture models. BIC and CAIC criterion are reported. K is the number of regimes. We use the aggregate measure of natural resources $x g d p$. Selected model in bold.

\begin{tabular}{|c|c|c|c|c|}
\hline \multirow[t]{2}{*}{ Variable } & \multicolumn{2}{|c|}{ Mixture } & \multicolumn{2}{|c|}{ Wald test } \\
\hline & $\underset{(35 \%)}{\operatorname{group}} 1$ & $\underset{(65 \%)}{\operatorname{group}} 2$ & statistic & $p$-value \\
\hline Intercept & $\begin{array}{l}17.955^{* * *} \\
(3.255)\end{array}$ & $\begin{array}{l}14.076^{* * *} \\
(3.981)\end{array}$ & 0.56 & 0.45 \\
\hline $\log (g d p)$ & $\begin{array}{l}-2.41^{* * * *} \\
(0.295)\end{array}$ & $\begin{array}{l}-1.441^{* * *} \\
(0.299)\end{array}$ & 5.38 & 0.02 \\
\hline $\log (\mathrm{pop}+0.05)$ & $\begin{array}{l}-3.821^{* * *} \\
(0.961)\end{array}$ & $\begin{array}{c}-6.593^{* * *} \\
(1.512)\end{array}$ & 2.28 & 0.13 \\
\hline $\log (i n v)$ & $\begin{array}{l}2.764^{* * *} \\
(0.334)\end{array}$ & $\begin{array}{l}1.068^{* *} \\
(0.431)\end{array}$ & 9.90 & 0.001 \\
\hline $\log (e d u c)$ & $\begin{array}{l}1.740^{* * *} \\
(0.307)\end{array}$ & $\begin{array}{l}0.481 \\
(0.408)\end{array}$ & 5.96 & 0.02 \\
\hline NR & ${ }_{(0.015)}^{0.066 * *}$ & $\begin{array}{c}-0.004 \\
(0.014)\end{array}$ & 11.44 & 0.001 \\
\hline eco & $\begin{array}{l}0.413^{* * *} \\
(0.134)\end{array}$ & $\begin{array}{l}1.439^{* * *} \\
(0.196)\end{array}$ & 18.78 & $<0.001$ \\
\hline dem & $\begin{array}{l}-0.168^{* * *} \\
(0.041)\end{array}$ & $\begin{array}{c}-0.102 \\
(0.061)\end{array}$ & 0.73 & 0.39 \\
\hline time dummies & .. &.. & & \\
\hline Concomitant & & & & \\
\hline Intercept & - & $\begin{array}{l}0.979 \\
(3.276)\end{array}$ & & \\
\hline$\overline{e c O}$ & - & $\begin{array}{l}0.648 \\
(0.651)\end{array}$ & & \\
\hline$\overline{d e m}$ & - & $\begin{array}{l}-0.452^{* *} \\
(0.195)\end{array}$ & & \\
\hline $\log \left(e d u c_{1970}\right)$ & - & $\begin{array}{l}0.921 \\
(0.539)\end{array}$ & & \\
\hline Lat & - & $\begin{array}{l}-9.094^{* * *} \\
(2.706)\end{array}$ & & \\
\hline$R^{2}$ & 0.51 & 0.29 & & \\
\hline
\end{tabular}

Table 5: Estimation results of the selected mixture model in table 4 where the measure of natural resources is $x g d p$. There are 91 countries and 498 observations. Time dummies are include. Standard errors in parenthesis. $* * *$ significant at $1 \%, * *$ significant at $5 \%$. 


\begin{tabular}{|c|c|c|c|}
\hline \multicolumn{2}{|l|}{ Group 1} & \multicolumn{2}{|l|}{ Group 2} \\
\hline Country & proba & Country & proba \\
\hline Australia & 0.96 & Algeria & 1 \\
\hline Austria & 0.99 & Argentina & 0.99 \\
\hline Bangladesh & 0.78 & Bahrain & 1 \\
\hline Belgium & 0.93 & Benin & 0.97 \\
\hline Botswana & 0.67 & Bolivia & 1 \\
\hline Canada & 0.99 & Brazil & 0.99 \\
\hline Colombia & 0.81 & Cameroon & 1 \\
\hline Congo. Rep, & 0.89 & Central African Rep, & 1 \\
\hline Cyprus & 0.99 & Chile & 1 \\
\hline Denmark & 0.99 & China & 0.77 \\
\hline Finland & 0.99 & Costa Rica & 0.99 \\
\hline France & 0.99 & Cote d'Ivoire & 0.99 \\
\hline Germany & 0.99 & Dominican Rep, & 0.99 \\
\hline Greece & 0.95 & Ecuador & 1 \\
\hline India & 0.99 & Egypt & 0.99 \\
\hline Israel & 0.99 & El Salvador & 1 \\
\hline Italy & 0.99 & Fiji & 1 \\
\hline Japan & 0.99 & Ghana & 1 \\
\hline Korea. Republic of & 0.86 & Guatemala & 1 \\
\hline Mali & 0.98 & Guyana & 1 \\
\hline Netherlands & 0.99 & Haiti & 0.99 \\
\hline Norway & 0.99 & Honduras & 1 \\
\hline Pakistan & 0.99 & Hungary & 1 \\
\hline Poland & 0.96 & Indonesia & 1 \\
\hline South Africa & 0.91 & Iran & 1 \\
\hline Spain & 0.99 & Ireland & 0.99 \\
\hline Sweden & 0.99 & Jamaica & 1 \\
\hline Switzerland & 0.99 & Jordan & 1 \\
\hline Tunisia & 0.97 & Kenya & 1 \\
\hline Turkey & 0.99 & Lesotho & 0.99 \\
\hline UK & 0.99 & Malawi & 1 \\
\hline \multirow[t]{28}{*}{ US } & 0.99 & Malaysia & 0.95 \\
\hline & & Mauritius & 0.99 \\
\hline & & Mexico & 1 \\
\hline & & Mozambique & 1 \\
\hline & & Nepal & 0.96 \\
\hline & & New Zealand & 0.99 \\
\hline & & Nicaragua & 1 \\
\hline & & Niger & 0.99 \\
\hline & & Panama & 1 \\
\hline & & Papua New Guinea & 1 \\
\hline & & Paraguay & 1 \\
\hline & & Peru & 1 \\
\hline & & Philippines & 1 \\
\hline & & Portugal & 0.95 \\
\hline & & Senegal & 0.64 \\
\hline & & Sierra Leone & 0.85 \\
\hline & & Singapore & 1 \\
\hline & & Sri Lanka & 0.99 \\
\hline & & Syria & 1 \\
\hline & & Tanzania & 0.99 \\
\hline & & Thailand & 1 \\
\hline & & Togo & 1 \\
\hline & & Trinidad Tobago & 1 \\
\hline & & Uganda & 0.95 \\
\hline & & Uruguay & 1 \\
\hline & & Venezuela & 1 \\
\hline & & Zambia & 1 \\
\hline & & Zimbabwe & 1 \\
\hline
\end{tabular}

Table 6: Classification obtained from the selected mixture model with $x g d p$ as the measure of natural resources. The numbers are the group membership posterior probabilities 


\begin{tabular}{lcl}
\hline & Group1 & Group2 \\
\hline \hline growth & 2.32 & 1.50 \\
& $(1.57)$ & $(3.24)$ \\
$\log (g d p)$ & 9.35 & 8.41 \\
& $(0.99)$ & $(0.85)$ \\
$\log ($ pop +0.05$)$ & 1.79 & 1.94 \\
& $(0.14)$ & $(0.14)$ \\
$\log (i n v)$ & 3.16 & 2.92 \\
& $(0.43)$ & $(0.52)$ \\
$\log ($ educ $)$ & 1.81 & 1.44 \\
& $(0.71)$ & $(0.62)$ \\
$\operatorname{xgdp}$ & $\mathbf{8 . 1 3}$ & $\mathbf{1 7 . 1 4}$ \\
& $\mathbf{( 6 . 1 9 )}$ & $\mathbf{( 1 3 . 1 1 )}$ \\
$\operatorname{demo}$ & 8.18 & 4.39 \\
& $(3.18)$ & $(3.78)$ \\
eco & 6.31 & 5.82 \\
& $(1.05)$ & $(1.05)$ \\
\hline
\end{tabular}

Table 7: Descriptive statistics by class from the classification obtained in table 6 , standard deviations in parenthesis

\begin{tabular}{|c|c|c|c|c|}
\hline \multicolumn{5}{|c|}{ Xgdp Components } \\
\hline & Metal-Ores & Agri-food & Fuel & \multirow{2}{*}{$\begin{array}{l}\text { Rent } \\
(4)\end{array}$} \\
\hline & $(1)$ & $(2)$ & $(3)$ & \\
\hline$\overline{\mathrm{K}=1}$ & $\begin{array}{l}2315.8 \\
{[2330.8]}\end{array}$ & $\begin{array}{l}2350.4 \\
{[2365.4]}\end{array}$ & $\begin{array}{l}2281.1 \\
{[2296.1]}\end{array}$ & $\begin{array}{l}2595.3 \\
{[2610.3]}\end{array}$ \\
\hline$K=2$ & $\begin{array}{l}2241.9 \\
{[2277.9]}\end{array}$ & $\begin{array}{l}2280.7 \\
{[2316.7]}\end{array}$ & $\begin{array}{l}2200.3 \\
{[2236.3]}\end{array}$ & $\begin{array}{l}2475.9 \\
{[2511.9]}\end{array}$ \\
\hline $\mathrm{K}=3$ & $\begin{array}{l}2263.9 \\
{[2320.9]}\end{array}$ & $\begin{array}{l}2289.7 \\
{[2346.7]}\end{array}$ & $\begin{array}{l}2209.4 \\
{[2266.4]}\end{array}$ & $\begin{array}{l}2477.3 \\
{[2534.3]}\end{array}$ \\
\hline $\mathrm{K}=4$ & $\begin{array}{l}2278.2 \\
{[2356.2]}\end{array}$ & $\begin{array}{l}2305.9 \\
{[2383.9]}\end{array}$ & $\begin{array}{l}2216.6 \\
{[2294.6]}\end{array}$ & $\begin{array}{l}2498.6 \\
{[2576.6]}\end{array}$ \\
\hline
\end{tabular}

Table 8: Goodness of fit with alternative measures of natural resources. BIC and CAIC (in brackets) are reported for each measure. Selected models are in bold. 


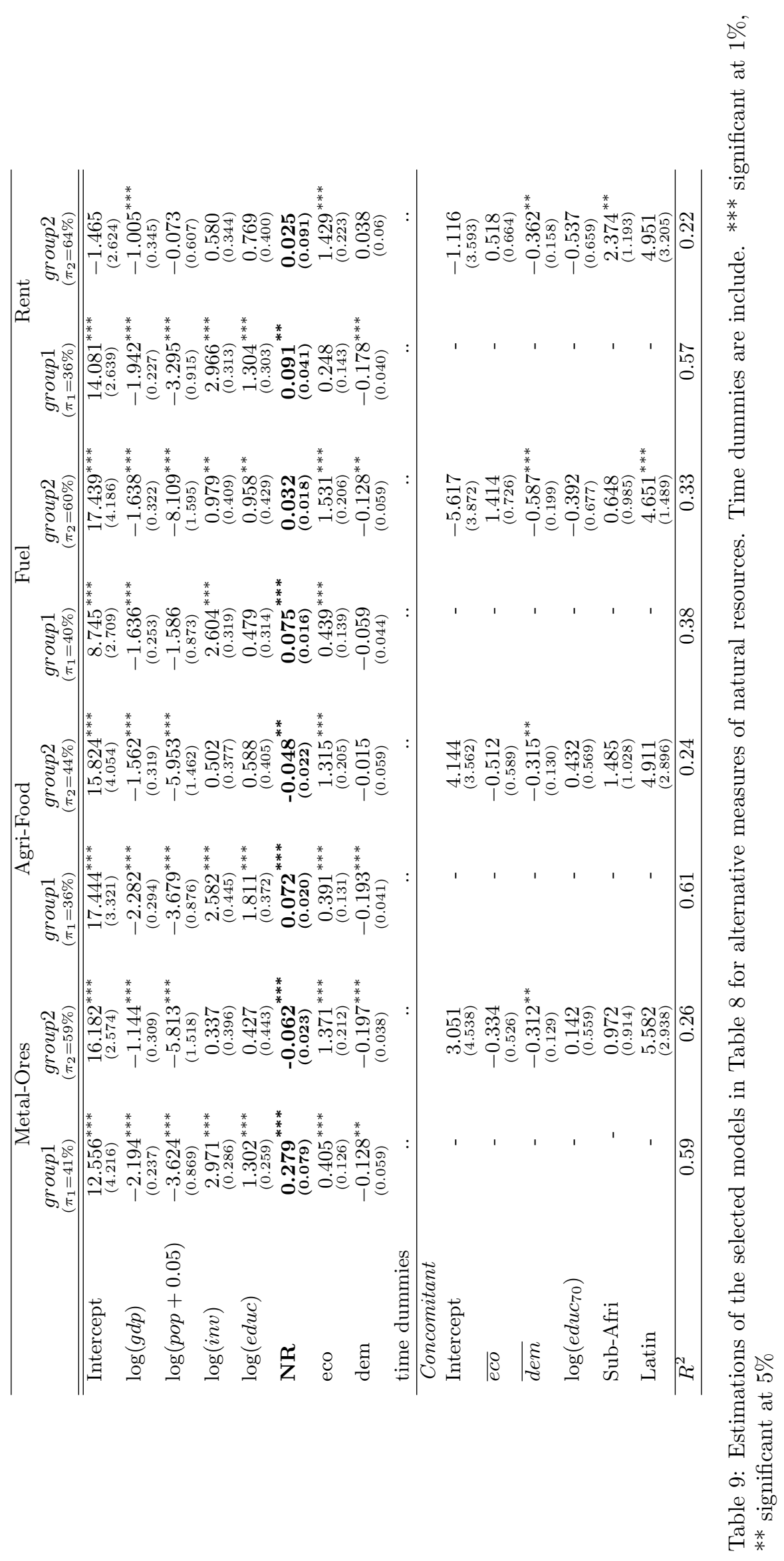




\begin{tabular}{|c|c|c|c|c|c|c|}
\hline \multirow[t]{2}{*}{ Variable } & \multicolumn{2}{|c|}{ Xgdp } & \multicolumn{2}{|c|}{ Ores-Metal } & \multicolumn{2}{|c|}{ Rent } \\
\hline & $\begin{array}{c}\text { group } 1 \\
(42 \%)\end{array}$ & $\begin{array}{c}\text { group } 2 \\
(58 \%)\end{array}$ & $\begin{array}{c}\text { group } 1 \\
\left(\pi_{1}=41 \%\right)\end{array}$ & $\begin{array}{c}\text { group } 2 \\
\left(\pi_{2}=59 \%\right)\end{array}$ & $\begin{array}{c}\text { group } 1 \\
\left(\pi_{1}=50 \%\right)\end{array}$ & $\begin{array}{c}\text { group } 2 \\
\left(\pi_{2}=50 \%\right)\end{array}$ \\
\hline Intercept & $\begin{array}{l}14.952^{* * *} \\
(2.732)\end{array}$ & $\begin{array}{l}13.367^{* * * *} \\
(4.205)\end{array}$ & $\begin{array}{l}16.060^{* * *} \\
(2.559)\end{array}$ & $\begin{array}{l}13.922^{* * *} \\
(4.269)\end{array}$ & $\begin{array}{l}3.056^{* *} \\
(1.492)\end{array}$ & $\begin{array}{c}7.929 \\
(4.917)\end{array}$ \\
\hline $\log \left(g d p_{0}\right)$ & $\begin{array}{l}-1.985^{* * *} \\
(0.243)\end{array}$ & $\begin{array}{l}-1.272^{* * *} \\
(0.313)\end{array}$ & $\begin{array}{l}-2.192^{* * *} \\
(0.234)\end{array}$ & $\begin{array}{l}-1.218^{* *} \\
(0.311)\end{array}$ & $\begin{array}{l}-1.810^{* * *} \\
(0.232)\end{array}$ & $\begin{array}{l}-1.013^{* * *} \\
(0.385)\end{array}$ \\
\hline $\log (p o p+0.05)$ & $\begin{array}{l}-3.355^{* * *} \\
(0.919)\end{array}$ & $\begin{array}{l}-5.749^{* * *} \\
(1.551)\end{array}$ & $\begin{array}{l}-3.608^{* * *} \\
(0.866)\end{array}$ & $\begin{array}{l}-6.019^{* * *} \\
(1.512)\end{array}$ & $\begin{array}{c}0.115 \\
(0.3)\end{array}$ & $\begin{array}{l}-4.306^{* *} \\
(1.738)\end{array}$ \\
\hline $\log (i n v)$ & $\begin{array}{l}2.544^{* * *} \\
(0.259)\end{array}$ & $\begin{array}{l}0.707 \\
(0.421)\end{array}$ & $\begin{array}{l}2.969^{* * *} \\
(0.278)\end{array}$ & $\begin{array}{l}0.441 \\
(0.404)\end{array}$ & $\begin{array}{l}2.957^{* * *} \\
(0.239)\end{array}$ & $\begin{array}{l}0.569 \\
(0.454)\end{array}$ \\
\hline $\log (e d u c)$ & $\begin{array}{l}1.754^{* * *} \\
(0.329)\end{array}$ & $\begin{array}{l}0.039 \\
(0.568)\end{array}$ & $\begin{array}{l}1.333^{* * *} \\
(0.256)\end{array}$ & $\begin{array}{l}0.022 \\
(0.478)\end{array}$ & $\begin{array}{l}2.437^{* * *} \\
(0.286)\end{array}$ & $\begin{array}{c}-0.509 \\
(0.736)\end{array}$ \\
\hline NR & ${ }_{(0.032)}^{0.098^{* * *}}$ & $\begin{array}{c}-0.065 \\
(0.045)\end{array}$ & $\begin{array}{l}0.388^{* *} \\
(0.192)\end{array}$ & $\begin{array}{l}-0.232^{* * *} \\
(0.079)\end{array}$ & $\begin{array}{l}0.962^{* * *} \\
(0.168)\end{array}$ & $\begin{array}{c}-0.222 \\
(0.261)\end{array}$ \\
\hline $\log (e d u c) * N R$ & $\begin{array}{l}-0.039^{* *} \\
(0.019)\end{array}$ & $\begin{array}{l}0.032 \\
(0.027)\end{array}$ & $\begin{array}{c}-0.069 \\
(0.111)\end{array}$ & $\begin{array}{l}0.123^{* *} \\
(0.055)\end{array}$ & $\begin{array}{l}-0.402^{* * *} \\
(0.077)\end{array}$ & $\begin{array}{l}0.159 \\
(0.174)\end{array}$ \\
\hline eco & $\begin{array}{l}0.290^{* *} \\
(0.127)\end{array}$ & $\begin{array}{l}1.305^{* * *} \\
(0.217)\end{array}$ & $\begin{array}{l}0.407^{* * *} \\
(0.126)\end{array}$ & $\begin{array}{l}1.339^{* * *} \\
(0.214)\end{array}$ & $\begin{array}{l}0.398^{* * *} \\
(0.151)\end{array}$ & $\begin{array}{l}1.527^{* * *} \\
(0.246)\end{array}$ \\
\hline dem & $\begin{array}{l}-0.186^{* * *} \\
(0.039)\end{array}$ & $\begin{array}{c}-0.039 \\
(0.059)\end{array}$ & $\begin{array}{l}-0.192^{* * *} \\
(0.038)\end{array}$ & $\begin{array}{c}-0.046 \\
(0.060)\end{array}$ & $\begin{array}{l}-0.140^{* * *} \\
(0.040)\end{array}$ & $\begin{array}{l}0.055 \\
(0.070)\end{array}$ \\
\hline time dummies & .. &. & .. &.. & .. & .. \\
\hline \multicolumn{7}{|l|}{ Concomitant } \\
\hline Intercept & - & $\begin{array}{l}1.438^{* * *} \\
(0.546)\end{array}$ & - & $\begin{array}{l}1.597^{* * *} \\
(0.562)\end{array}$ & - & $\begin{array}{l}0.396 \\
(0.599)\end{array}$ \\
\hline$\overline{d e m}$ & - & $\begin{array}{l}-0.343^{* * *} \\
(0.092)\end{array}$ & - & $\begin{array}{l}-0.363^{* * *} \\
(0.095)\end{array}$ & - & $\begin{array}{l}-0.228^{* *} \\
(0.091)\end{array}$ \\
\hline Latin & - & $\begin{array}{l}4.683 \\
(2.483)\end{array}$ & - & $\begin{array}{l}5.329^{* *} \\
(2.623)\end{array}$ & - & $\begin{array}{l}5.037 \\
(2.672)\end{array}$ \\
\hline Sub-afri & & & & & - & $\begin{array}{l}0.411 \\
(0.730)\end{array}$ \\
\hline$R^{2}$ & 0.27 & 0.56 & 0.28 & 0.59 & 0.28 & 0.57 \\
\hline
\end{tabular}

Table 10: Estimation results of the mixture model with the interact term between education and natural resource. Time dummies are include. ${ }^{* * *}$ significant at $1 \%,{ }^{* *}$ significant at $5 \%$. We include to the concomitant variables a Latin American dummy Latin and a Sub-African dummy Sub-afri to controle for geography. 


\begin{tabular}{|c|c|c|c|c|c|c|}
\hline & \multicolumn{2}{|c|}{ xgdp } & \multicolumn{2}{|c|}{ Metal-Ores } & \multicolumn{2}{|c|}{ Rent } \\
\hline & $\begin{array}{c}\text { group } 1 \\
\left(\pi_{1}=45 \%\right)\end{array}$ & $\begin{array}{c}\text { group } 2 \\
\left(\pi_{2}=55 \%\right)\end{array}$ & $\begin{array}{l}\text { group } 1 \\
\left(\pi_{1}=43 \%\right)\end{array}$ & $\begin{array}{c}\text { group } 2 \\
\left(\pi_{2}=57 \%\right)\end{array}$ & $\begin{array}{c}\text { group } 1 \\
\left(\pi_{1}=41 \%\right)\end{array}$ & $\begin{array}{c}\text { group } 2 \\
\left(\pi_{2}=59 \%\right)\end{array}$ \\
\hline Intercept & $\begin{array}{l}16.824^{* * *} \\
(3.295)\end{array}$ & $\begin{array}{l}11.407^{* * *} \\
(4.218)\end{array}$ & $\begin{array}{l}16.958^{* * *} \\
(2.919)\end{array}$ & $\begin{array}{l}11.955^{* * *} \\
(4.389)\end{array}$ & $\begin{array}{l}19.015^{\text {*** }} \\
(2.743)\end{array}$ & $\begin{array}{c}-3.774 \\
(2.845)\end{array}$ \\
\hline $\log (g d p)$ & $\begin{array}{l}-2.016^{* * *} \\
(0.287)\end{array}$ & $\begin{array}{l}-1.446^{* * *} \\
(0.327)\end{array}$ & $\begin{array}{l}-2.271^{* * *} \\
(0.243)\end{array}$ & $\begin{array}{l}-1.449^{* * *} \\
(0.328)\end{array}$ & $\begin{array}{l}-2.324^{* * *} \\
(0.251)\end{array}$ & $\begin{array}{l}-1.044^{* * *} \\
(0.377)\end{array}$ \\
\hline $\log (p o p+0.05)$ & $\begin{array}{l}-3.559^{* * *} \\
(1.036)\end{array}$ & $\begin{array}{l}-5.222^{* * *} \\
(1.410)\end{array}$ & $\begin{array}{l}-3.823^{* * *} \\
(1.002)\end{array}$ & $\begin{array}{l}-5.068^{* * *} \\
(1.437)\end{array}$ & $\begin{array}{l}-4.445^{* * *} \\
(0.919)\end{array}$ & $\begin{array}{l}0.088 \\
(0.616)\end{array}$ \\
\hline $\log (i n v)$ & $\begin{array}{l}2.489^{* * *} \\
(0.296)\end{array}$ & $\begin{array}{l}0.979^{* *} \\
(0.417)\end{array}$ & $\begin{array}{l}3.138^{* * *} \\
(0.293)\end{array}$ & $\begin{array}{l}0.608 \\
(0.398)\end{array}$ & $\begin{array}{l}2.956^{* * *} \\
(0.314)\end{array}$ & $\begin{array}{l}0.509 \\
(0.366)\end{array}$ \\
\hline $\log (e d u c)$ & $\begin{array}{l}1.287^{* * *} \\
(0.339)\end{array}$ & $\begin{array}{l}0.823^{* *} \\
(0.416)\end{array}$ & $\begin{array}{l}1.135^{* * *} \\
(0.265)\end{array}$ & $\begin{array}{l}0.855^{* *} \\
(0.426)\end{array}$ & $\begin{array}{l}1.339^{* * *} \\
(0.353)\end{array}$ & $\begin{array}{l}0.806 \\
(0.422)\end{array}$ \\
\hline NR & $\begin{array}{l}0.039^{* * *} \\
(0.01)\end{array}$ & $\begin{array}{c}-0.018 \\
(0.017)\end{array}$ & $\begin{array}{l}0.278^{* * *} \\
(0.079)\end{array}$ & $\begin{array}{l}-0.086^{* * *} \\
(0.033)\end{array}$ & $\begin{array}{l}0.088^{*} \\
(0.045)\end{array}$ & $\begin{array}{l}0.119 \\
(0.104)\end{array}$ \\
\hline eco & $\begin{array}{l}0.201^{* * *} \\
(0.135)\end{array}$ & $\begin{array}{l}1.306^{* *} \\
(0.214)\end{array}$ & $\begin{array}{l}0.346^{* * *} \\
(0.132)\end{array}$ & $\begin{array}{l}1.319^{* * *} \\
(0.22)\end{array}$ & $\begin{array}{l}0.273 \\
(0.165)\end{array}$ & $\begin{array}{l}1.762^{\text {*** }} \\
(0.252)\end{array}$ \\
\hline demautoc & $\begin{array}{l}-1.328^{* * *} \\
(0.322)\end{array}$ & $\begin{array}{c}-0.169 \\
(0.399)\end{array}$ & $\begin{array}{l}-1.302^{* * *} \\
(0.291)\end{array}$ & $\begin{array}{c}-0.117 \\
(0.393)\end{array}$ & $\begin{array}{l}-1.120^{* * *} \\
(0.314)\end{array}$ & $\begin{array}{l}0.226 \\
(0.455)\end{array}$ \\
\hline time dummies & .. & .. & .. & .. & .. & .. \\
\hline \multicolumn{7}{|l|}{ Concomitant } \\
\hline Intercept & - & $\begin{array}{l}0.512 \\
(0.396)\end{array}$ & - & $\begin{array}{l}0.624 \\
(0.385)\end{array}$ & - & $\begin{array}{l}0.299 \\
(0.501)\end{array}$ \\
\hline demautoc $_{70}$ & - & $\begin{array}{l}-1.882^{* * *} \\
(0.700)\end{array}$ & - & $\begin{array}{l}-2.058^{* * *} \\
(0.671)\end{array}$ & - & $\begin{array}{l}-2.575^{* * *} \\
(0.899)\end{array}$ \\
\hline pres $_{70}$ & - & $\begin{array}{l}-1.916 \\
(2.215)\end{array}$ & - & $\begin{array}{l}-1.971 \\
(2.339)\end{array}$ & - & $\begin{array}{l}-3.445 \\
(2.533)\end{array}$ \\
\hline Sub-afri & - & & & & - & $\begin{array}{l}2.783^{* *} \\
(1.356)\end{array}$ \\
\hline Latin & - & $\begin{array}{l}-4.766^{* *} \\
(2.128)\end{array}$ & - & $\begin{array}{l}4.733^{* *} \\
(2.151)\end{array}$ & - & $\begin{array}{l}5.223^{* *} \\
(2.434)\end{array}$ \\
\hline$R^{2}$ & 0.53 & 0.28 & 0.59 & 0.28 & 0.54 & 0.25 \\
\hline
\end{tabular}

Table 11: Alternative measures of institutions. We replace the variable dem by a binary variable demautoc which takes the value of 1 for democracies and 0 for autocracies. The variable pres in the concomitant variable is equal to 1 for presidential democracies and 0 for the parliamentary or mixed democracies. Time dummies are include. ${ }^{* * *}$ significant at $1 \%,{ }^{* *}$ significant at $5 \%,{ }^{*}$ significant at $10 \%$ 